\title{
MERCATORIA
}

Available online http://ojs.uma.ac.id/index.php/mercatoria

\section{Urgensi Perlindungan bagi Korban Kekerasan Seksual dalam Sistem Peradilan Pidana Terpadu Berkeadilan Gender}

\author{
Atikah Rahmi * \\ Universitas Muhammadiyah Sumatera Utara \\ *Corresponding author: E-mail: atikahrahmi@umsu.ac.id
}

\begin{abstract}
Abstrak
Masalah kekerasan seksual merupakan bentuk kejahatan yang melecehkan dan menodai harkat kemanusiaan, serta patut dikategorikan sebagai jenis kejahatan luar biasa (extra ordinary crime), oleh karenanya penanganannya harus luas biasa juga. Upaya untuk menghentikan kekerasan merupakan hal penting, karena kekerasan telah menimbulkan berbagai luka pada korban. Trauma yang berkepanjangan dialami oleh korban, perasaan malu, ketakutan, sehingga mengakibatkan korban terkadang sulit untuk mengungkapkan kembali kekerasan yang pernah dialaminya.Dalam penangangannya, tidak sedikit kasus kekerasan terhadap anak dan perempuan yang mengambang tanpa solusi hukum yang jelas. Sistem Peradilan Pidana Terpadu (SPPT) merupakan salah satu terobosan untuk mengubah sistem hukum yang tidak berperspektif gender menjadi berperspektif gender.Sistem tersebut diharapkan mampu merespon situasi yang senantiasa dialami oleh perempuan korban kekerasan seksual yang berbasis gender.
\end{abstract}

Kata kunci : Kekerasan Seksual, Sistem Peradilan Pidana Terpadu, Berkeadilan Gender

\begin{abstract}
The issue of sexual violence is a form of crime that harasses and tarnish the dignity of humanity, and deserves to be categorized as a type of extraordinary crime, therefore its treatment must be widespread as well. Attempts to stop violence are important, because violence has caused many injuries to the victim. Prolonged trauma experienced by the victim, feelings of shame, fear, resulting victim sometimes difficult to revisit violence ever dialaminya.Dalam handling, not a few cases of violence against children and women who float without a clear legal solution. The Integrated Criminal Justice System (SPPT) is one of the breakthroughs to change the legal system with no gender perspective to be gender perspective. The system is expected to be able to respond to situations always experienced by women victims of gender-based sexual violence.
\end{abstract}

Keyword: Sexual Violence, Integrated Criminal Justice System, Gender Justice

How to Cite: Rahmi, A., (2018), Urgensi Perlindungan bagi Korban Kekerasan Seksual dalam Sistem Peradilan Pidana Terpadu Berkeadilan Gender, Mercatoria, 11 (1): 37-60. 
Atikah Rahmi, Urgensi Perlindungan bagi Korban Kekerasan Seksual dalam Sistem Peradilan Pidana Terpadu Berkeadilan Gender

\section{PENDAHULUAN}

Diskursus tentang anak tidak akan pernah berhenti sepanjang sejarah kehidupan, karena anak adalah amanah dan karunia Allah, yang dalam dirinya melekat harkat dan martabat sebagai manusia seutuhnya. Anak merupakan tunas, potensi dan generasi muda penerus cita-cita perjuangan bangsa yang memiliki peran strategis, ciri dan sifat khusus sehingga wajib dilindungi dari segala bentuk perlakuan tidak manusiawi yang mengakibatkan terjadinya pelanggaran hak asasi manusia.

Negara menjunjung tinggi hak asasi anak yang ditandai dengan adanya jaminan perlindungan dan pemenuhan hak anak dalam Undang-Undang Dasar Negara Republik Indonesia Tahun 1945 yang dikuatkan dengan ratifikasi konvensi internasional tentang Hak Anak melalui Keputusan Presiden No. 36 Tahun 1990 Tentang Pengesahan Convention On The Rights Of The Child. Sebagai implementasi dari Konvensi tersebut, pemerintah telah mengesahkan UU No. 23 Tahun 2002 Tentang Perlindungan Anak yang dirubah denganUU No. 35 Tahun 2014 Tentang Perubahan atas UU No. 23 Tahun 2002 Tentang Perlindungan Anak. telah mengatur prinsip-prinsip umum perlindungan anak, yaitu prinsip non diskriminasi, prinsip kepentingan terbaik anak, prinsip kelangsungan hidup dan tumbuh kembang serta prinsip partisipasi anak (Dalam Penjelasan Umum UU No. 35 Tahun 2014 Tentang Perubahan Atas UU No. 23 Tahun 2002 Tentang Perlindungan Anak disebutkan; bahwa negara, pemerintah, pemerintah Daerah, masyarakat dan orang tua berkewajiban untuk memberikan perlindungan dan menjamin terpenuhinya hak asasi anak sesuai dengan tugas dan tanggungjawabnya, perlindungan terhadap anak yang dilakukan berdasarkan prinsip hak asasi manusia yaitu; penghormatan, pemenuhan dan perlindungan atas hak anak).

Masa kanak-kanak adalah dimana anak sedang dalam proses tumbuh kembangnya. Oleh karena itu, anak wajib dilindungi dari segala kemungkinan kekerasan, terutama kekerasan seksual. Setiap anak berhak mendapatkan perlindungan. Upaya perlindungan terhadap anak harus diberikan secara utuh, menyeluruh dan komprehensif, tidak memihak kepada suatu golongan atau kelompok anak. Upaya yang diberikan tersebut dilakukan dengan mempertimbangkan kepentingan terbaik bagi anak dengan mengingat haknya untuk hidup dan berkembang, serta tetap menghargai pendapatnya. Upaya perlindungan terhadap anak berarti terwujudnya keadilan dalam suatu masyarakat. Asumsi ini diperkuat dengan pendapat Age yang dikutip oleh Gosita (1996), mengemukakan bahwa "melindungi anak pada hakekatnya melindungi keluarga, masyarakat, bangsa dan negara di masa depan".

Begitu pentingnya upaya perlindungan anak demi kelangsungan masa depan sebuah komunitas, baik komunitas yang terkecil yaitu keluarga, maupun komunitas yang terbesar yaitu negara. Artinya, dengan mengupayakan perlindungan bagi anak di komunitaskomunitas tersebut tidak hanya telah menegakkan hak-hak anak, tapi juga sekaligus menanam investasi untuk kehidupan mereka di masa yang akan 
datang. Menurut Abu Hurairah, hal ini tentu saja perlu dilakukan agar kelak tidak terjadi generasi yang hilang (lost generation) (Abu Huraerah. 2006).

Anak yang hakekatnya belum matang secara fisik dan mental, seyogianya harus dilindungi hak-haknya, dicukupi kebutuhannya, dihargai pendapatnya, diberikan pendidikan yang terbaik bagi mereka serta diperhatikan perkembangannya.Namun sepanjang tahun 2016 dan 2017 ini, masyarakat Indonesia terus berduka dengan kasus kejahatan kekerasan seksual terhadap perempuan dan anak yang marak terjadi. Kekerasan terhadap perempuan dan anak sejak lama menjadi salah satu masalah dalam upaya perlindungan perempuan dan anak. Masalah kekerasan seksual merupakan salah satu bentuk kejahatan yang melecehkan dan menodai harkat kemanusiaan, serta patut dikategorikan sebagai jenis kejahatan melawan kemanusiaan (crime against humanity). Kasus kejahatan kekerasan seksual terhadap siswi SMP di Bengkulu yang berujung kematian akibat diperkosa dan dibunuh, menyusul kasus kekerasan seksual yang terjadi di Lampung, Manado, Sidoarjo, Jawa Timur dan bahkan masih banyak kasus kekerasan seksual lainnya yang tidak terungkap. Kasus kejahatan kekerasan seksual terhadap perempuan dan anak yang terjadi seperti fenomena gunung es, karena yang terjadi jauh lebih banyak dari yang diungkapkan ke permukaan.

Berdasarkan data dari Pusat Data dan Informasi Komnas Perlindungan anak Indonesia, terdapat 21.869.797 kasus pelanggaran hak anak yang tersebar di 34 provinsi dan 179 kabupaten/kota, dimana sebesar 42-58\% dari pelanggaran hak anak tersebut merupakan kejahatan seksual terhadap anak dan selebihnya adalah kasus kekerasan fisik dan penelantaran anak. Sementara itu data catatan akhir tahun (catahu) Komnas Perempuan 2015, terdapat 1.033 kasus perkosaan, 834 kasus pencabulan, 184 kasus pelecehan seksual, 74 kasus kekerasan seksual lain, 46 kasus melarikan anak perempuan dan 12 kasus percobaan perkosaan. Data tersebut menunjukkan adanya kekerasan terhadap perempuan di ranah personal yang mencapai 8.626 kasus yang terdiri atas 5.102 kekerasan terhadap isteri, 1.748 kasus kekerasan dalam pacaran, 843 kasus kekerasan terhadap anak perempuan, 750 kasus kekerasan dalam relasi personal lain, 63 kasus kekerasan dari mantan pacar dan 53 kasus kekerasan terhadap pekerja rumah tangga (Andika Wijaya, Wida Peace Ananta. 2016).

Kekerasan seksual merupakan istilah yang menunjuk pada perilaku seksual diviatif atau hubungan seksualyang menyimpang, merugikan pihak korban (Pembahasan masalah korban dan perlindungannya merupakan studi tentang viktimologi, lihat Siswanto Sunarso. 2015. Viktimologi dalam Sistem Peradilan Pidana. Sinar Grafika: Jakarta, halaman !. Pengertian viktimologi berasal dari kata victim (korban) dan logi (ilmu pengetahuan) yang mengandung arti ilmu pengetahuan tentang korban (kejahatan), lihat Bambang Waluyo.2011. Viktimologi Perlindungan Korban dan Saksi. Sinar Grafika: Jakarta, halaman 9. Viktimologi memberikan pemahaman dan mencerahkan permasalahan kejahatan dengan mempelajari para korban 
Atikah Rahmi, Urgensi Perlindungan bagi Korban Kekerasan Seksual dalam Sistem Peradilan Pidana Terpadu Berkeadilan Gender

kejahatan, proses viktimisasi dan sepanjang hidup si korban dan akan akibatnya dalam rangka menciptakan kebijaksanaan dan tindakan pencegahan serta menekan kejahatan secara lebih bertanggungjawabLihat Arif Gosita. 1993. Masalah Korban Kejahatan. Jakarta: Akademika Presindo, halaman 40) dan merusak kedamaian di tengah masyarakat. Kejahatan kekerasan seksual berakibat pada penderitaan korban yang membutuhkan perhatian serius (Abdul Wahid, Muhammadi Irfan. 2001). Pengungkapan kasus kejahatan kekerasan seksual ini amat rumit, karena terkait dengan tradisi dan budaya atau pandangan keagamaan masyarakat yang mentabukan bicara seks di depan orang lain. Lebih dari itu pengungkapannya oleh korban seringkali semakin menambah penderitaan diri perempuan dan keluarganya.

Penderitaan korban dan keluarganya atas kejadian yang dialami akan berkepanjangan, apalagi ketika korban hamil akibat kejahatan seksual berupa perkosaan yang dilakukan manusia yang tidak berprikemanusiaan seperti yang terjadi pada seorang gadis tidak berdosa (NR) 14 tahun di Sidoarjo, Jawa Timur. Gadis tersebut bersama keluarganya terpaksa harus tinggal di rumah kecil eks kandang bebek, akibat diusir dari kontrakannya karena hamil akibat perbuatan keji dua (2) orang pria yang telah memperkosanya. Penderitaan tersebut tentunya juga dirasakan oleh keluarga korban yang dibunuh oleh pelaku setelah diperkosa beramai-ramai seperti yang dialami Yuyun (Bengkulu). Kejahatan kekerasan seksual berupa perkosaan mempunyai dampak yang tidak ringan terhadap korbannya yang akan berbekas mempengaruhi cara bertindak dan berpikir si korban.

Tindakan kekerasan merupakan wujud penindasan dan pelanggaran hak asasi yang dilakukan seseorang kepada orang lain, kelompok tertentu kepada kelompok lain, orang dewasa kepada anak-anak, majikan kepada pembantunya dan laki-laki kepada perempuan. Tindakan ini mencerminkan pihak yang labih kuat cenderung superior dan menempatkan pihak yang lemah sebagai korbannya (Abdul Wahid, Muhammadi Irfan).

Fakta-fakta di atas tentu sangat memprihatinkan, sebab realitas tersebut telah meningkat kepada situasi: "Kegentingan Kekerasan Seksual". Kekerasan Seksual yang dialami perempuan sudah dalam kondisi darurat untuk segera ditangani secara tepat dan adil, komprehensif dan holistik. Keadaan darurat ini tercermin dari kejadian kekerasan seksual di semua ranah: personal, publik dan Negara, yang menimpa korban dari rentang usia balita, anak-anak, remaja dan bahkan lansia.

Pemerintah telah menetapkan kejahatan seksual terhadap anak sebagai kejahatan luar biasa, sebab kejahatan itu dapat mengancam dan membahayakan jiwa anak. Di antara pro dan kontra soal urgensi penerbitan Perppu, Presiden mengambil keputusan radikal yang dianggap dapat dijadikan sebagai tonggak kepeloporan dalam perlindungan anak di Indonesia. Untuk itu, dikeluarkan Perppu No. 1 Tahun 2016 Tentang Perubahan Kedua UU No. 23 Tahun 2002 Tentang Perlindungan Anak yang telah ditandatangani oleh Presiden pada tanggal 25 Mei 2016. Perppu tersebut mengatur 
mengenai pidana pemberatan, pidana tambahan dan tindakan lain bagi pelaku. Pemberatan pidana berupa tambahan pidana sepertiga dari ancaman penjara paling singkat 10 tahun. Selain itu ancaman hukuman seumur hidup dan hukuman mati. Untuk tambahan pidana yang diatur adalah pengumuman identitas pelaku, kebiri kimia dan pemasangan alat deteksi elektronik yang bertujuan untuk menimbulkan efek jera terhadap pelaku.

Tambahan hukuman pidana berupa kebiri yang diatur dalam Perppu justeru menimbulkan pro dan kontra di masyarakat. Ikatan Dokter Indonesia (IDI) menolak menjadi eksekutor hukuman kebiri yang akan diberlakukan sebagai hukuman tambahan bagi pelaku kejahatan seksual sebagaimana disebutkan dalam Perppu tersebut. Pelaksanaan hukuman kebiri oleh dokter dianggap melanggar sumpah dokter dan kode etik kedokteran Indonesia. Sikap dokter atas pelaksanaan hukuman kebiri tersebut tentunya menjadi dilema, sebab hanya dokter yang berkompeten untuk melakukan eksekutor atas hukuman kebiri tersebut. Hukuman kebiri juga hampir tidak memiliki korelasi dengan berkurangnya kejahatan seksual pada anak.Mengebiri pelaku bukan jalan keluar yang adil bagi korban, tidak ada hubungan yang signifikan antara kebiri dan berkurangnya kejahatan seksual anak, korban tidak akan pulih dengan diberikannya hukuman tambahan kebiri kepada pelaku.

Upaya untuk menghentikan kekerasan merupakan hal penting, karena kekerasan telah menimbulkan berbagai luka pada pihak korban. Dampak dari luka tersebut mengakibatkan korban sulit untuk mengungkapkan kembali kekerasan yang pernah dialaminya. Negara bertangungjawab untuk melindungi anakanak dari kejahatan seksual dan memberikan pemulihan kepada para korban serta memastikan hak-hak mereka. Perlu adanya peraturan yang mewajibkan pelaku untuk memberikan restitusi dan kompensasi kepada korban dalam rangka memulihakan hak-hak korban secara total.

Tulisan ini bertujuan untuk menjelaskan urgensi perlindungan terhadap korban kekerasan seksual, baik perempuan maupun anak dalam sistem peradilan pidana terpadu yang berkeadilan gender. Sistem Peradilan Pidana Terpadu (SPPT) merupakan salah satu terobosan untuk mengubah sistem hukum yang tidak berperspektif jender menjadi berperspektif gender. Sistem peradilan pidana di dalamnya terkandung gerak sistemik dari subsistem pendukungnya, yaitu; Kepolisian, Kejaksaan, Pengadilan, Lembaga Pemasyarakatan, dan Advokat yang secara keseluruhan merupakan satu kesatuan yang berusaha mentransformasikan masukan menjadi luaran yang merupakan tujuan dari sistem peradilan pidana.

\section{METODE PENELITIAN}

Penelitian hukum merupakan upaya untuk mencari dan menemukan pengetahuan yang benar mengenai hukum. Mencari dan menemukan itu tentu saja ada caranya, yaitu melalui metode (M. Syamsudin, 2007). Dalam penelitian ini menggunakan penelitian normatif, yaitu melakukan kajian terhadap berbagai peraturan perundang-undangan yang berkaitan dengan Urgensi Perlindungan bagi Korban Kekerasan Seksual dalam Sistem Peradilan Pidana Terpadu 
Atikah Rahmi, Urgensi Perlindungan bagi Korban Kekerasan Seksual dalam Sistem Peradilan Pidana Terpadu Berkeadilan Gender

Berkeadilan Gender. Penelitian hukum normatif atau penelitian hukum kepustakaan adalah penelitian hukum yang dilakukan dengan cara meneliti bahan pustaka atau bahan sekunder belaka (Soerjono Soekanto dan Sri Mamudji, 2001). Di dalam penelitian hukum normatif, maka penelitian terhadap asas-asas hukum dilakukan terhadap kaidah-kaidah hukum, yang merupakan patokan-patokan berprilaku atau bersikap tidak pantas (Nomensen Sinamo, 2009).

\section{HASIL DAN PEMBAHASAN \\ Kejahatan Kekerasan Seksual}

Kejahatan seksual merupakan suatu tindakan yang melanggar kesopanan dalam arti kesusilaan, perasaan malu yang berhubungan dengan nafsu kelamin misalnya bersetubuh dimuka umum, meraba buah dada perempuan, memperlihatkan anggota kemaluan wanita atau pria, mencium dan sebagainya ( $R$. Susilo. 1995). Kejahatan kekerasan seksual dapat terjadi dalam berbagai bentuk; seperti prostitusi, perzinahan, perkosaan, pencabulan maupun pelecehan seksual yang dialami perempuan dan anak. Sexsual abuse (kekerasan seksual) menunjuk kepada setiap aktivitas seksual, bentuknya dapat berupa penyerangan atau tanpa penyerangan. Kategori penyerangan menimbulkan penderitaan berupa cedera fisik, kategori kekerasan seksual tanpa penyerangan menderita trauma emosional. Bentuk-bentuk kekerasan seksual: dirayu, dicolek, anal seks, diperkosa (Maidin Gultom. 2012).

Banyak sekali definisi tentang kekerasan terhadap perempuan, di antaranya adalah yang diberikan oleh
Heise (1994), bahwa kekerasan terhadap perempuan adalah segala tindakan kekerasan verbal atau fisik, pemaksaan atau ancaman pada nyawa yang diarahkan kepada seorang perempuan, baik anakanak atau telah dewasa, yang menyebabkan kerugian fisik, penghinaan dan perampasan kebebasan sehingga melanggengkan subordinasi perempuan". Definisi ini belum menampilkan analisis gender (Gender merupakan sebuah istilah yang menunjukkan pembagian peran social antara laki-laki dan perempuan yang mengacu kepada pemberian cirri emosional dan psikologis yang diharapkan oleh budaya tertentu disesuaikan dengan fisik laki-laki dan perempuan. (Lihat Zaitunah Subhan. 2015. Al Qur'an dan Perempuan Menuju Kesetaraan Gender Dalam Penafsiran. Prenada Media Grup: Jakarta, halaman 2. lihat pula Mansur Fakih. 1996. Analisis Gender \& Transformasi Sosial. Pustaka Pelajar: Yogyakarta, halaman 8). Kendati menyinggung perempuan sebagai korban kekerasan, tetapi definisi ini lebih terfokus pada kekerasan fisik, sementara kekerasan psikis, ekonomi, seksual dan sebagainya yang justru banyak menimpa perempuan.

Soetandyo (2000), mendefisikan kekerasan sebagai suatu tindakan yang dilakukan oleh seseorang atau sejumlah orang yang berposisi kuat (merasa kuat) kepada seseorang atau sejumlah orang yang berposisi lemah (dipandang lemah/dilemahkan), yang dengan sarana kekuatannya, baik secara fisik maupun non-fisik dengan sengaja dilakukan untuk menimbulkan penderitaan kepada obyek kekerasan.Kekerasan seksual termasuk dalam ruang lingkup pelecehan seksual, 
yaitu segala macam bentuk perilaku yang berkonotasi atau mengarah kepada hal-hal seksual yang dilakukan secara sepihak dan tidak diharapkan oleh orang yang menjadi sasaran sehinga menimbulkan reaksi negatif seperti malu, marah, benci, tersinggung, dan sebagainya pada diri individu yang menjadi korban pelecehan tersebut (Witriyatul Jauhariyah "Akar Kekerasan Seksual Terhadap Perempuan" Jurnal

Perempuan. http://www.jurnalperempuan.org/blogmuda1/-akar-kekerasan-seksualterhadap-perempuan, diakses tanggal 06 Juni 2017).

Ahmad Sofian mendefinisikan Kekerasan seksual terhadap anak sebagai hubungan atau interaksi antara seorang anak dengan seseorang yang lebih tua atau anak lebih banyak nalar atau orang dewasa seperti orang asing, saudara kandung atau orang tua dimana anak tersebut dipergunakan sebagai sebuah objek pemuas bagi kebutuhan seksual si pelaku (Ahmad Sofian. 2012). Perbuatanperbuatan tersebut dilakukan dengan menggunakan paksaan, ancaman, suap, tipuan dan tekanan.

Kekerasan terhadap perempuan dapat didefinisikan secara sederhana sebagai segala bentuk perilaku yang dilakukan kepada perempuan yang memunculkan akibat psikis berupa perasaan takut hingga akibat berupa perlukaan fisik. definisi ini sedemikian luasnya sehingga meliputi mulai dari pelecehan seksual berupa siulan atau godaan terhadap perempuan, hingga pembiaran oleh Negara pada kondisi perempuan warga negaranya yang menjadi korban kekerasan (Niken Savitri. 2008).
Pasal 1 Deklarasi Penghapusan Kekerasan Terhadap Perempuan disebutkan bahwa yang dimaksud dengan kekerasan terhadap perempuan adalah setiap perbuatan berdasarkan perbedaan jenis kelamin yang berakibat atau mungkin berakibat kesengsaraan atau penderitaan perempuan secara fisik, seksual atau psikologis, termasuk ancaman perbuatan tertentu, pemaksaan atau perampokan kemerdekaan secara sewenang-wenang, baik yang terjadi di depan umum maupun dalam kehidupan pribadi.

Sementara itu, dalam Rancangan Undang-Undang tentang Penghapusan Kekerasan Seksual disebutkan pengertian kekerasan seksual, yaitu; "Setiap perbuatan melanggar martabat kemanusiaan seseorang berdasarkan diskriminasi gender yang menyasar pada tubuh dan seksualitas seseorang, yang berakibat atau dapat berakibat kerugian atau penderitaan fisik, psikis, ekonomi, seksual, politik dan atau sosial korban". Dokumen Rencana Aksi Nasional Penghapusan Kekerasan Terhadap Perempuan (RAN-PKTP), menggunakan definisi kerja berikut: "kekerasan terhadap perempuan adalah setiap tindakan yang melanggar, menghambat, meniadakan kenikmatan dan pengabaian terhadap hak asasi perempuan atas dasar gender. Tindakan tersebut mengakibatkan kerugian dan penderitaan pada perempuan di sepanjang hidupnya baik secara fisik, seksual atau psikis, termasuk ancaman perbuatan tersebut, paksaan atau perampasan kemerdekaan secara sewenang-wenang baik dalam kehidupan keluarga, bermasyarakat dan bernegara. 
Atikah Rahmi, Urgensi Perlindungan bagi Korban Kekerasan Seksual dalam Sistem Peradilan Pidana Terpadu Berkeadilan Gender

Bentuk-bentuk Kejahatan Seksual yaitu: (1) perkosaan; (2) pelecehan seksual; (3) eksploitasi seksual; (4) penyiksaan seksual; (5) perbudakan seksual; (6) intimidasi/serangan bernuansa seksual termasuk ancaman atau percobaan pemerkosaan; prostitusi paksa; (8) pemaksaan kehamilan; (9) pemaksaan aborsi; (10) pemaksaan perkawinan; perdagangan perempuan untuk tujuan seksual; (12) control seksual termasuk pemaksaan cara berbusana yang menjadi kriminalisasi perempuan lewat peraturan atas nama moralitas dan agama; (13) penghukuman yang tidak manusiawi dan bernuansa seksual; (14) praktik tradisi yang bertema seksual yang membahayakan perempuan.

Mariana Amiruddin berbendapat bahwa Kekerasan seksual seringkali dianggap sebagai kejahatan terhadap kesusilaan (kejahatan terhadap moral) semata. Pandangan semacam ini bahkan didukung oleh negara dalam Kitab Undang-Undang Hukum Pidana (KUHP). Dalam KUHP kekerasan seksual seperti perkosaan dianggap sebagai pelanggaran terhadap kesusilaan. Pengkategorian ini tidak melihat dan memahami secara utuh tentang sebab-sebab dan berbagai akibat terjadinya perkosaan terhadap perempuan, sehingga pencarian keadilan bagi perempuan atas kekerasan seksual yang menimpanya menjadi sulit ditegakkan. Lebih lanjut Mariana Amiruddin menjelaskan bahwa berdasarkan definisi "kejahatan asusila" tersebut, perempuan menjadi terbungkam dan sulit melaporkan apa yang menimpanya. Sebab, pandangan tentang asusila yang terjadi pada tubuh perempuan hubungannya dengan seks, biasanya pertanyaan tentang masih perawan atau tidak sebelum pernikahannya, kekhawatiran dianggap tidak bermoral sudah tidak perawan sebelum menikah ini, sehingga bukan lagi dianggap sebagai perkosaan (Mariana Amiruddin, "Kekerasan Seksual Bukan Kejahatan Seksual Melainkan Kriminal" http://www.komnasperempuan.go.id/wpcontent/uploads/2015/01/KekerasanSeksual-Bukan-Kejahatan, diakses tanggal 4 Juli 2017).

Sehubungan dengan pendapat Mariana Amiruddin, Nursyahbani Katjasungkana menyatakan bahwa masalah perkosaan yang dialami perempuan merupakan contoh kerendahan posisi perempuan terhadap kepentingan seksual laki-laki. Citra seksual perempuan yang telah menempatkan dirinya sebagai objek seksual laki-laki ternyata berimplikasi jauh. Dalam kehidupan kesehariannya perempuan senantiasa berhadapan dengan kekerasan, pemaksaan dan penyiksaan fisik dan psikis. Oleh karena itulah, perkosaan bukan hanya cerminan dari citra perempuan sebagai objek seks, melainkan sebagai objek kekuasaan lakilaki.

Kekerasan seksual terhadap perempuan dan anak hakekatnya merupakan salah satu bentuk kekerasan menunjukkan kerentanan posisi perempuan dan atau anak, terhadap kepentingan seksual laki-laki. Citra seksual anak perempuan yang telah ditempatkan sebagai obyek seksual lakilaki berimplikasi pada kehidupannya, sehingga dia sebagai korban terpaksa 
harus menghadapi kekerasan, pemaksaan dan penyiksaan fisik serta psikis.

Pada prinsipnya, Islam tidak menginginkan adanya kekerasan sebagaimana dijelaskan dalam Qur'an Surat al-Hujurat [49]:11. "Hai orang-orang yang beriman, janganlah komunitas lakilaki merendahkan komunitas yang lain, boleh jadi yang direndahkan itu lebih baik dari mereka yang merendahkan. Dan jangan pula komunitas perempuan merendahkan komunitas perempuan yang lain, boleh jadi yang direndahkan itu lebih baik. Dan janganlah suka mencela dirimu sendiri dan jangan memanggil dengan panggilan yang mengandung pelecehan. Sikap dan tindakan merendahkan dan melecehkan itu adalah perilaku yang buruk dari seorang yang telah beriman. Barangsiapa yang tidak kembali memperbaiki diri maka mereka itulah orang-orang yang zalim".

\section{Akar Kekerasan Seksual terhadap Perempuan}

Kekerasan merupakan salah satu bentuk dari fenomena ketidakadilan gender (Ketidakadilan Gender muncul karena adanya kesalahpahaman terhadap konsep gender yang disamakan dengan konsep seks, sekalipun kata gender dan seks secara bahasa memang mempunyai makna yang sama, yaitu jenis kelamin. Konsep seks merupakan sesuatu yang bersifat kodrati, dibawa sejak lahir, dan tak bisa berubah-ubah, seperti menstruasi, hamil, melahirkan, menyusui, sedangkan laki-laki tidak. Sementara konsep gender bukanlah suatu yang bersifat kodrati atau alami, tetapi merupakan hasil konstruksi sosial dan kultural yang telah berproses sepanjang sejarah manusia. misalnya perempuan itu lembut, emosional, sementara laki-laki kuat dan rasionnal. (Zaitunah Subhan)). Terjadinya kekerasan terhadap perempuan, merupakan akibat dari stereotype, marjinalisasi dan subordinasi terhadapnya. Ketika terjadi kekerasan terhadap perempuan, orang dengan mudah mengatakan karena perempuan lemah, pantas menerimanya atau sebutan-sebutan lain yang justru tidak memberikan penguatan dan membuat hati dan psikis perempuan korban kekerasan merasa terlindungi.

Perempuan yang secara umum memiliki fisik yang lebih lemah dibandingkan laki-laki, juga mengakibatkan pelabelan (stereotyping) bahwa perempuan juga lemah dalam segala hal. Hal ini, seringkali dimanfaatkan laki-laki untuk mendiskriminasikan perempuan atau meminggirkan perempuan, sehingga tidak melibatkan perempuan dalam peran-peran strategis sebaliknya, perempuan berada dalam posisi subordinasi dan marginalisasi. Akibat dari pelabelan tersebut, seringkali laki-laki memanfatkan kekuatannya untuk melakukan kekerasan terhadap perempuan, baik secara fisik, psikis maupun seksual.

Ketimpangan relasi kuasa berbasis gender diperparah ketika satu pihak (pelaku) memiliki kendali lebih terhadap korban, baik ekonomi, pengetahuan, status sosial dan lain-lainnya. Kendali muncul dalam bentuk hubungan patron-klien, seperti antara orangtua-anak, majikanburuh, guru-murid, tokoh masyarakat atau tokoh agama-warga, pengasuh-santri dan kelompok bersenjata/aparat-penduduk sipil, bahkan orang pusat-orang daerah. (Baca: Catahu Komnas Perempuan, 
Atikah Rahmi, Urgensi Perlindungan bagi Korban Kekerasan Seksual dalam Sistem Peradilan Pidana Terpadu Berkeadilan Gender

2013).Kekuasaan yang memiliki legitimasi hukum, juga sering menjadi sarana untuk melakukan kekerasan terhadap bawahannya. Hakikat kekuasaan sesungguhnya adalah kewajiban untuk mengatur, bertanggungjawab dan melindungi bawahannya. Namun, seringkali yang terjadi adalah bahwa dengan sarana kekuasaan yang legitimate, penguasa melakukan kekerasan yang justru tidak melindungi warga atau bawahannya.Dalam konteks ini misalnya, negara terhadap rakyat, suami terhadap istri dan anak-anak dan sebagainya.

Kekerasan terhadap perempuan senantiasa langgeng terjadi sebab perempuan dengan tubuhnya yang khas dipahami sebagai makhluk sekunder, objek, dapat diperlakukan seenakknya dan dapat menjadi hak milik. Dalam berbagai kasus kekerasan terhadap perempuan, dilihat beberapa faktor yang mendasari tindakan tersebut, antara lain: a) Karakteristik fisik dan reproduksinya perempuan memang lebih mudah menjadi korban kekerasan, khususnya kekerasan seksual, seperti perkosaan atau penghamilan paksa; b) Dalam relasinya dengan laki-laki, pemaknaan sosial dari perbedaan biologis tersebut menyebabkan memantapnya mitos, streotipe, aturan, praktik yang merendahkan perempuan dan memudahkan terjadinya kekerasan. Kekerasan dapat berlangsung dalam keluarga dan relasi personal, bisa pula di tempat kerja atau melalui praktik-praktik budaya; c) Dari sisi ekonomi, perempuan dapat dijadikan sarana pengeruk keuntungan, sehingga merebaklah pelacuran, perdagangan perempuan (woman trafficking), atau pornografi; d) Kekerasan terhadap perempuan sekaligus dapat digunakan sebagai sarana terror, penghinaan, atau ajakan perang pada kelompok lain. Kesucian perempuan dilihat sebagai kehormatan masyarakat, sehingga penghinaan atau perusakan kesucian perempuan akan dipahami sebagai penghinaan terhadap masyarakat (Mariana Amiruddin. "Perkosaan Bukan Soal Seks, Tapi Kekuasaan" Jurnal Perempuan; 2006).

Perempuan yang secara umum memiliki fisik yang lebih lemah dibandingkan laki-laki, mengakibatkan pelabelan (stereotyping) bahwa perempuan juga lemah dalam segala hal. Hal ini, seringkali dimanfaatkan laki-laki untuk mendiskriminasikan perempuan atau meminggirkan perempuan, sehingga tidak melibatkan perempuan dalam peran-peran strategis sebaliknya, perempuan berada dalam posisi subordinasi dan marginalisasi. Akibat dari pelabelan tersebut, seringkali laki-laki memanfaatkan kekuatannya untuk melakukan kekerasan terhadap perempuan, baik secara fisik, psikis maupun seksual.

Raymond A. Knight dalam Jurnal Perempuan edisi 71 tentang Perkosaan dan Kekuasaan (ditulis oleh Mariana Amiruddin berjudul "Perkosaan Bukan Soal Seks, Tapi Kekuasaan") memaparkan bahwa terdapat metode penelitian yang disebut Etiologi, adalah studi tentang akar atau penyebab mengapa sesuatu terjadi. Metode ini mengatakan ada dua hal penyebab perkosaan sehingga mengorbankan perempuan, yaitu oleh mitos dan mis persepsi terhadap bahasa perempuan. Raymond A. Knight, Ph.D dari Brandeis University mempresentasikan hasil penelitiannya dalam metode Etiologi 
untuk meneliti para pelaku pemerkosaan berjudul "Preventing Rape: What the Research Tells Us" pada tahun 2011, mengungkapkan bahwa profil pemerkosa rata-rata bukan karena tidak bisa mengendalikan nafsu, bukan karena keinginan seksual yang tidak bisa dikontrol, bukan karena hasrat seksual, melainkan karena fantasi kekuasaan untuk menaklukkan tubuh seseorang secara seksual (Raymond A. Knight dalam Jurnal Perempuan edisi 71 tentang Perkosaan dan Kekuasaan (ditulis oleh Mariana Amiruddin berjudul "Perkosaan Bukan Soal Seks, Tapi Kekuasaan”).

Kesimpulan dari penelitian ini mengatakan bahwa perkosaan bukanlah tentang seks, tapi tentang kekuasaan. Perkosaan bukan karena seorang pria terbawa hasrat dan keinginan seks dan bukan tentang daya tarik seksual sama sekali tetapi tentang cara mengontrol korban dan menghapus otonomi mereka dan kemanusiaan. Budaya patriarkhi, yakni budaya yang berpusat pada laki-laki dan untuk kepentingan laki-laki, menjadi penyebab dan kontribusi terbesar bagi terjadinya kekerasan terhadap perempuan.Sebuah Ideologi yang melegitimasi laki-laki sebagai pemegang otoritas dan superioritas. Keyakinan bahwa perempuan secara kodrat adalah makhluk yang lembut dan lemah, posisinya di bawah laki-laki, inferior, melayani hasrat seksual laki-laki dan sebagainya telah menempatkan perempuan seakan-akan sah untuk ditaklukkan dan diperlakukan sesuai keinginan laki-laki, termasuk dengan caracara kekerasan. Ideologi patriarkis ini mempengaruhi cara berfikir masyarakat, mempengaruhi penafsiran atas teks-teks agama dan juga para pengambil kebijakan. Pengaruh ini melampaui ruang dan waktu kehidupan manusia, baik dalam domain privat (domestik) maupun publik. Ketimpangan yang didasarkan atas ideologi patriarki tersebut berpotensi menciptakan ketidakadilan, subordinasi dan dominasi atas perempuan. Ketimpangan tersebut merupakan sumber utama tindak kekerasan terhadap perempuan.

Budaya patriarki yang masih subur di masyarakat mengajarkan anak laki-laki dengan ego maskulinitas sementara femininitas diabaikan dan di anggap sebagai sifat yang nista. Para orang tua sangat bangga ketika anak laki-laki mereka mempunyai sifat maskulin, macho dan jantan. Sementara mereka diolok-olok jika anak laki-laki mempunyai sifat feminin. Sebagai contoh, masyarakat seperti membiarkan jika ada laki-laki bersiul dan menggoda perempuan yang melintas di jalan, tindakan mereka seolaholah menjadi hal yang lumrah dan wajar sebab sebagai laki-laki mereka beranggapan harus berani mengahadapi perempuan, laki-laki dianggap sebagai kaum penggoda sementara perempuan adalah objek atau makhluk yang pantas digoda dan tubuh perempuan dijadikan sebab kekerasan itu sendiri (Witriyatul Jauhariyah "Akar Kekerasan Seksual Terhadap Perempuan" Jurnal Perempuan. http://www.jurnalperempuan.org/blogmuda1/-akar-kekerasan-seksualterhadap-perempuan, diakses tanggal 06 Juni 2017).

Melalui budaya ini pula, lahir banyak sistem dan kebijkan yang tidak mengakomodir kebutuhan dan kepentingan perempuan. Oleh karena itu, 
Atikah Rahmi, Urgensi Perlindungan bagi Korban Kekerasan Seksual dalam Sistem Peradilan Pidana Terpadu Berkeadilan Gender

kekerasan terjadi di hampir semua lini kehidupan. Masyarakat kerapkali menimpakan kesalahan kepada perempuan ketika terjadi tindak kekerasan seksual berupa perkosaan. Perempuan yang sudah menjadi korban perkosaan justeru dianggap sebagai penyebab terjadinya peristiwa tersebut. Mereka disalahkan, karena memamerkan bagian-bagian tubuhnya yang terlarang (aurat) di depan publik. Mereka tidak menutupinya atau tidak mengenakan hijab. Perempuanlah yang menciptakan "fitnah" (menggoda dan memicu hasrat seksual) laki-laki.

Kekerasan seksual, terutama perkosaan sering dianggap sebagai aib bagi keluarga atau orang-orang terdekat, maka melaporkannya berarti membuka aib bagi seluruh sanak saudara, mereka khawatir menganggap salah satu keluarganya dicap tidak bermoral meskipun dengan alasan menjadi korban. Tubuh perempuan yang tidak perawan ibarat barang bekas yang tidak bisa dibeli saat perkawinan. Perkosaan adalah salah satunya, dan perempuan akan mengalami perasaan malu yang luar biasa, terkadang korban yang justru disalahkan yaitu dianggap menggoda, memancing, memakai pakaian tidak sopan, mau saja berdua-duaan, genit, keluar malam hari sendirian, dan sebagainya. Sebaliknya, pelaku malah dianggap wajar melakukan perkosaan atas hal-hal tersebut.

Asusmi-asumsi

sebagaimana dijelaskan di atas, justeru berkembang di masyarakat. Mengapa perempuanyang tidak melakukan tindak kejahatan harus dipersalahkan dan berhak dilecehkan bahkan diperkosa karena pakaian yang dipilihnya. Padahal kekerasan seksual juga ada terjadi terhadap perempuan berjilbab. Pada sisi lain perempuan tanpa jilbab juga tidak selalu menimbulkan perkosaan atau kekerasan seksual dalam bentuk lainnya. Orang yang melihat perempuan tanpa jilbab tidak selalu melakukan pelecehan dan perkosaan. Ini menunjukkan bahwa antara perkosaan dan penampilan tidak berjilbab tidak memiliki hubungan sebab akibat. Demikian juga alasan bahwa perkosaan terjadi karena pelaku terpengaruh oleh gambar-gambar porno atau menonton video porno. Tidak semua orang yang melihat gambar atau menonton video porno terlibat dalam aksi kekerasan seksual. Faktor-faktor ini lebih sekedar sebagai pemicu belaka bagi munculnya impuls-impuls hasrat birahi laki-laki terhadap perempuan.

Masyarakat kerapkali bersuudzhon terhadap korban, malah menyalahkan korban yang sudah terzholomi haknya. Karena mayoritas korban adalah perempuan, maka perlu ditekankan bahwa perkosaan terjadi bukan karena pakaian atau penampilan, melainkan kesempatan (opportunity) dan kerentanan. Kerentanan termasuk situasi mental, fokus, waspada dan sadar situasi. Seorang perempuan yang "tidak mengenakan pakaian yang mengundang" bukan berarti dapat menghindari perkosaan, karena dari hasil penelitian diketahui bahwa appearance/penampilan bukan sebab perkosaan.

\section{Perlindungan bagi Korban Kekerasan Seksual dalam Sistem Peradilan Pidana Terpadu Berkeadilan Gender}

Kasus kekerasan seksual terhadap perempuan terutama anak, semakin marak terjadi, bahkan sudah termasuk 
darurat kekerasan seksual, namun tidak semua dari kasus tersebut yang terungkap ke publik. Kasus kekerasan seksual yang terjadi seperti fenomena gunung es, karena yang terungkap jauh lebih sedikit dari fakta yang terjadi.Kasus kekerasan seksual terhadap perempuan dan anak juga mengalami peningkatan di Provinsi Sumatera Utara setiap tahunnya, bahkan pada tahun 2014 Sumatera Utara telah menyandang Status "Darurat Perlindungan Anak".Berdasarkan hasil penelitian di Pusat Kajian dan Perlindungan Anak (PKPA) didapatkan bahwa kekerasan seksual terhadap anak selalu merupakan kekerasan yang mendominasi di Sumatera Utara. Berikut ditampilkan kasus yang terjadi kurun waktu 2014-2016:

\section{Sumber: Pusat Kajian dan Perlindungan Anak (PKPA) Medan}

Tabel di atas menunjukkan jenis kejahatan seksual yang terjadi dan ditangani oleh Pusat Kajian dan Perlindungan Anak (PKPA) Medan berbentuk; pencabulan, eksploitasi seksual anak dan trafficking, pemerkosaan, persetubuhan anak dan incest. Kasus yang tinggi di tahun 2014 yaitu eksploitasi seksual anak dan Trafficking yaitu sebanyak 20 kasus. Di tahun 2015 yang paling tinggi adalah kasus pencabulan yaitu sebanyak 16 kasus, sementara di tahun 2016 pencabulan tetap mendominasi yaitu sebanyak 14 kasus.

Perlindungan terhadap korban kejahatan seksual, merupakan hal yang sangat urgen untuk diberikan. Dampak dari kejahatan seksual yang dirasakan korban sangatlah berat dan berakibat pada trauma yang berkepanjangan dan depresi. Untuk itu perlu penanganan khusus terhadap anak dan perempuan korban kejahatan seksual, termasuk upaya pemulihan pasca kekerasan yang dialaminya. Cukup banyak penganiayaan atau penyalahgunaan seksual masa kecil yang dilakukan oleh orang-orang terdekat korban, yang berdampak psikologis untuk jangka panjang.

$\begin{array}{ccc}\text { Upaya } & \text { perlindungan } & \text { hukum } \\ \text { terhadap } & \text { perempuan } & \text { korban }\end{array}$ pemerkosaanbaik anak maupun dewasa, merupakan perjuangan atas hak-hak mereka. Hak sebagai anak dan hak sebagai perempuan merupakan bagian dari hak asasi manusia yang wajib dijamin, dilindungi dan dipenuhi.Bentuk perlindungan korban dapat dilakukan dengan reparasi (pemulihan kondisi

\begin{tabular}{|l|l|l|l|}
\hline Jenis kasus & $\begin{array}{l}\text { Tahun } \\
\mathbf{2 0 1 4}\end{array}$ & $\begin{array}{l}\text { Tahun } \\
\mathbf{2 0 1 5}\end{array}$ & $\begin{array}{l}\text { Tahun } \\
\mathbf{2 0 1 6}\end{array}$ \\
\hline Pencabulan & 7 kasus & 16 kasus & 14 kasus \\
\hline $\begin{array}{l}\text { Eksploitasi } \\
\text { Seksual anak } \\
\text { dan Traficking }\end{array}$ & 20 kasus & 5 kasus & 1 Kasus \\
\hline Pemerkosaan & 1 kasus & 1 kasus & 1 \\
\hline $\begin{array}{l}\text { Persetubuhan } \\
\text { anak }\end{array}$ & 4 kasus & 4 kasus & 3 kasus \\
\hline Incest & - & 4 kasus & - \\
\hline Jumlah & 32 kasus & 30 kasus & 18 kasus. \\
\hline
\end{tabular}

korban), konpensasi (ganti kerugian yang diberikan oleh negara karena pelaku tidak mampu memberikan ganti kerugian sepenuhnya yang menjadi tanggung jawabnya), restitusi (ganti kerugian yang diberikan kepada korban atau keluarganya oleh pelaku atau pihak ketiga, dapat berupa pengembalian harta milik, pembayaran ganti kerugian untuk kehilangan atau penderitaan, atau penggantian biaya untuk tindakan 
Atikah Rahmi, Urgensi Perlindungan bagi Korban Kekerasan Seksual dalam Sistem Peradilan Pidana Terpadu Berkeadilan Gender

tertentu) dan rehabilitasi (upaya pemulihan korban).

Selama ini berkembang pemikiran bahwa dengan telah diadilinya pelaku kejahatan dan selanjutnya pelaku menjalani hukuman, maka perlindungan hukum terhadap korban dianggap telah sepenuhnya diberikan. Akibatnya, ketika korban kemudian menuntut adanya pemberian ganti kerugian hal tersebut dianggap merupakan tindakan yang berlebihan (Dikdik M. Arief Mansur. Elisatris Gultom. 2008). Korban kejahatan yang pada dasarnya merupakan pihak yang paling menderita dalam suatu tindak pidana, justru tidak memperoleh perlindungan sebanyak yang diberikan oleh undang-undang kepada pelaku kejahatan. Akibatnya, pada saat pelaku kejahatan telah dijatuhi sanksi pidana oleh pengadilan, kondisi korban kejahatan seperti tidak diperdulikan sama sekali. Padalah, masalah keadilan dan penghormatan hak asasi manusia tidak hanya berlaku terhadap pelaku kejahatan saja, tapi juga korban kejahatan (Dikdik M. Arief Mansur. Elisatris Gultom. 2008). Kedudukan korban sebagai subjek hukum memiliki kedudukan sederajat di depan hukum (equality before the law).

Penanganan kasus kekerasan seksual terhadap perempuan dan anak, perlu dilakukan sinergi antara keluarga, masyarakat dan negara. Dalam penanganan kasus kekerasan seksual terhadap anak dan perempuan seharusnya bersifat holistik dan terintegrasi. Semua sisi memerlukan pembenahan dan penanganan, baik dari sisi medis, sisi individu, aspek hukum (dalam hal ini masih banyak mengandung kelemahan), maupun dukungan sosial. Apabila kekerasan seksual terhadap anak dan perempuan tidak ditangani secara serius dapat menimbulkan dampak sosial yang luas di masyarakat. Penyembuhan trauma psikis akibat kekerasan seksual haruslah mendapat perhatian besar dari semua pihak yang terlibat (Ivo Noviana, Kekerasan Seksual Terhadap Anak: Dampak dan Penanganannua melalui https://media.neliti.com/media/publicati ons/52819-ID-kekerasan-seksualterhadap-anak-dampak-d.pdf2015, diakses tanggal 05 Juli 2017).

Penyelesaian kasus kekerasan seksual terhadap anak menurut Leden Marpaung paling banyak menimbulkan kesulitan, baik pada tahap penyidikan, penuntutan, maupun pada tahap penjatuhan putusan. Selain kesulitan dalam batasan di atas, juga kesulitan pembuktian misalnya perkosaan atau perbuatan cabul yang umumnya dilakukan tanpa kehadiran orang lain. KUHPidana memang ada menegaskan perlindungan terhadap perempuan dari kekerasan dandiskriminasi namun berbagai kekerasan seksual belum dikenali secara utuh. KUHPidana menerapkan definisi perkosaan secara sempit, perkosaan dilihat hanya dalam bentukpenetrasi organ-organ seksual. Unsur-unsur perkosaan dalam KUHP mensyaratkan adanya kekerasanatau ancaman kekerasan serta persetubuhan yang dilakukan di luar perkawinan. Selain itu, sistem pembuktian yang digunakan aparat penegak hukum juga mensyaratkan adanya bukti sperma dan kekerasan (Leden Marpaung. 1996).

Menurut Muladi, dalam rangka pengaturan hukum pidana terhadap korban kejahatan secara mendasar dikenal dua model, yakni model hak-hak 
prosedural (the procedural rights model) dan model pelayanan (the service model). Pada model pertama, penekanan diberikan pada dimungkinkannya korban untuk memainkan peranan aktif, dalam proses kriminal atau dalam jalannya proses peradilan. Dalam hal ini, korban diberi hak untuk mengadakan tuntutan pidana atau untuk membantu jangka atau hak untuk dihadirkan dan didengar di setiap tingkatan sidang pengadilan, dimana kepentingannya terkait di dalamnya, termasuk hak untuk diminta konsultasi oleh lembaga pemasyarakatan, sebelum diberikan lepas bersyarat dan pada akhirnya hak untuk mengadakan perdamaian atau peradilan perdata. Pendekatan semacam ini, melihat korban sebagai seorang subjek yang harus diberi hak-hak juridis yang luas untuk menuntut dan mengejar kepentingannya (Muladi. 2002).

Model pelayanan (service model), penekanan diletakkan pada perlunya diciptakan standar baku bagi pembinaan korban kejahatan, yang dapat digunakan oleh polisi, misalnya dalam bentuk pedoman dalam rangka motifikasi kepada korban dan atau kejaksaan dalam rangka penanganan perkaranya, pemberian kompenssasi sebagai sanksi pidana yang bersifat restitutif dan dampak pernyataan korban sebelum pidana dijatuhkan. Pendekatan ini, melihat korban kejahatan sebagai sasaran khusus untuk dilayani dalam kerangka kegiatan polisi dan para penegak hukum yang lain.

Menurut Dikdik M. Arief Mansur dan Elisatris Gultom, dalam penyelesaian perkara pidana, banyak ditemukan korban kejahatan kurang memperoleh perlindungan hukum yang memadai, baik perlindungan yang sifatnya immaterial maupun materiil. Korban kejahatan ditempatkan sebagai alat bukti yang memberi keterangan yaitu hanya sebagai saksi, sehingga kemungkinan korban untuk memperoleh keluasan dalam memperjuangkan haknya sangat kecil (Dikdik M. Arief Mansur. Elisatris Gultom).

Fakta di lapangan bahwa perempuan korban kekerasan baik di sektor domestik maupun publik berhadapan dengan sistem peradilan pidana (criminal justice system), sering mendapat respons negatif bahkan mengalami pelecehan seksual. Korban masih sering dipersalahkan dan tidak diberi perlindungan seperti apa yang dibutuhkannya. Menurut Achie Sudiarti Luhulima, dalam memperlakukan korban selama proses peradilan pidana, aparat penegak hukum (polisi, jaksa, hakim) masih memperlakukan korban kekerasaan seksual sebagai obyek, bukan subjek yang harus didengarkan dan dihormati hak-hak hukumnya. Mereka kebanyakan masih menjadikan korban sebagai korban untuk kedua kalinya (revictimisasi) atas kasus yang dialaminya. Korban masih sering dipersalahkan dan tidak diberi perlindungan seperti apa yang dibutuhkannya.Akibatnya, semakin banyak kasus tidak dilaporkan atau malah ditarik kembali dan tidak dilanjutkan ke pengadilan. Hal ini menambah deretan kekerasan terselubung tanpa pernah terungkap dan para pelakunya bebas dari jeratan hukum (Achie Sudiarti Luhulima (Penyunting). 2000).

Menurut Azmiati Zuliah, dalam proses penyidikan, Polisi bahkan sering kali mengungkapkan bahwa mereka memiliki keterbatasan dana sehingga agak 
Atikah Rahmi, Urgensi Perlindungan bagi Korban Kekerasan Seksual dalam Sistem Peradilan Pidana Terpadu Berkeadilan Gender

sulit untuk bergerak, oleh karenanya korban dan keluarganya terkadang dibebankan juga untuk mencari pelaku. Pergantian Kanit dan Juru periksa juga kerap kali menyebabkan kasus yang dilaporkan menjadi kabur. Keadaan ini yang mengakibatkan kasus kejahatan seksual terhadap perempuan dan anak banyak yang mengambang begitu saja. Lebih lanjut Azmiati Zuliah menjelaskan bahwa kondisi tersebut terjadi karena aparat kepolisian belum menjadikan kasus kekerasan seksual terhadap perempuan dan anak ini sebagai prioritas, sehingga mereka terkadang menganggap sepele dengan laporan korban (Hasil wawancara dengan Azmiati Zuliah (Koordinator Unit Pusat Informasi dan Pengaduan Anak PKPA) tanggal 14 Juli 2017).

Sebagai korban, tentunya membutuhkan perhatian dan perlindungan dari masyarakat, terutama ketika ia melaporkan kasusnya kepada pihak kepolisian. Seharusnya korban mendapatkan pelayanan yang prima, dengan ketersediaan Ruang Pelayanan Khusus (RPK) untuk penerimaan laporan korban kekerasan seksual anak dan perempuan (Ruang Pelayanan Khusus (RPK) hanya di Polda Sumut dan di Polrestabes Medan, di Polda namanya disebut dengan Renakda (Remaja, anakanak dan dewasa), sedangkan di Polrestabes Medan disebut dengan unit PPA (Perlindungan Perempuan dan Anak). Sementara di polsek-polsek belum disediakan, sampai hari ini, masih ditangani oleh Direskrim umum. Namun, walaupun Polda Sumut dan Polrestabes Medan sudah memiliki unit pelayanan khusus, tetapi anggota-anggota didalamnya belum didominasi oleh polisi wanita (polwan). Seharusnya ketika melaporkan kasusnya, korban diterima oleh Polwan, sehingga ia tidak malu dan lebih terbuka dalam memberikan keterangan dan menceritakan kronologis peristiwa kekerasan seksual yang telah dialaminya), termasuk fasilitasi untuk melakukan visum at repertum di kepolisian, sehingga dapat membantu meringankan penderitaan korban dalam proses penyidikan. Kejelasantentang mengapa peristiwa tersebut dialami dan siapa yang bertanggungjawab atas peristiwa tersebut selayaknya diketahui oleh korban.Korban juga berhak untuk mengetahui pelanggaran-pelanggaran apa saja yangtelah dialaminyadan berhak untukmemperoleh informasi yang lengkap dan akurat tentang peluang-peluang dan pilihan yangtersedia untuk mendapatkan kebenaran, keadilan, dan pemulihan; serta bagaimana negara mengambilperan dalam penyediaan pilihan tersebut.

Hukum positif di Indonesia prinsipnya merupakan suatu aturan yang salah satu tujuannya adalah untuk mencegah terjadinya kejahatan. Hal ini berarti, hukum juga bertujuan untuk melindungi masyarakat agar tidak menjadi korban kejahatan sebelum kejahatan itu terjadi. Berdasarkan ilmu hukum, maka pihak korban dapat menuntut kerugian atau ganti rugi terhadap pihak terpidana. Perlindungan korban diatur dalam Pasal 14c ayat (1) Kitab Undang-Undang Hukum Pidana (KUHP) yang berbunyi:

Pada perintah yang tersebut dalam Pasal 14a kecuali dalam hal dijatuhkan pidana denda, maka bersama-sama dengan syarat umum, bahwa orang yang dipidana tak akan melakukan tindak pidana, hakim boleh 
mengadakan syarat khusus bahwa orang yang dipidana itu akan mengganti kerugian yang terjadi karena tindak pidana itu, semuanya atau sebagiannya saja, yang akan ditentukan pada perintah itu juga, yang kurang dari masa percobaan itu.

Berdasarkan ketentuan Pasal $14 c$ ayat (1), Pasal $14 a$ dan $b$ KUHP, hakim dapat menjatuhkan pidana dengan menetapkan syarat khusus kepada terpidana dengan maksud untuk mengganti kerugian yang ditimbulkan kepada korban. Selain KUHPidana, Kitab Undang-Undang Hukum Acara Pidana (KUHAP) juga mengatur tentang perlindungan terhadap korban kejahatan seksual. Sebagaimana diatur dalam Bab III KUHAP, Tentang Penggabungan Perkara Ganti Kerugian, Pasal 98 s/d 101 yaitu tentang ganti rugi yang diberikan oleh korban dengan menggabungkan perkara pidana dan perdata. KUHAP mengatur perlindungan terhadap korban, sehingga selain pelaku mendapatkan hukuman yang setimpal dengan perbuatannya, korban juga mendapatkan ganti rugi atas kerugian yang dideritanya. Namun faktanya menurut Azmiati Zuliah, selama ini jaksa belum pernah mengajukan gugatan ganti kerugian dalam perkara kekerasan seksual yang ditanganinya. Gugatan ganti kerugian hanya ada dalam tulisan peraturan perundang-undangan saja. Menurut beliau, pernah diajukan ganti kerugian sebesar 46 juta rupiah dan disetujui oleh hakim, namun hanya sekedar di atas kertas semata (Hasil wawancara dengan Azmiati Zuliah (Koordinator Unit Pusat Informasi dan Pengaduan Anak PKPA) tanggal 14 Juli 2017).
Akar persoalan tersebut disebabkan sistem hukum di Indonesia yang belum sepenuhnya berpihak kepada kepentingan korban. Ketentuan hukum dalam Kitab Undang-Undang Hukum Acara Pidana (KUHAP) bahwa Tersangka/terdakwa lebih memiliki banyak akses untuk berinteraksi dengan aparatur penegak hukum dibandingkan dengan korban. Korban hanya berinteraksi dengan penyidik pada saat pelaporan/pengaduan dan berinteraksi dengan hakim serta jaksa penuntut umum pada saat pemeriksaan di pengadilan. Korban tidak pernah diikutsertakan pada saat penyidik berkomunikasi atau menyerahkan berkas perkara kepada jaksa penuntut umum. Dengan kata lain, KUHAP tidak memberi akses jaksa Penuntut Umum berhubungan dengan korban sebelum proses pemeriksaan perkara sampai ke pengadilan.

Sistem peradilan pidana yang diatur dalam KUHAP merupakan gambaran bahwa komponen hukum pidana yang dimilikibelum mampu mengawal penegakan hukum pidana materil (Sidik Sunaryo, 2005). Kelemahan mendasar yang terlihat dari KUHAP adalah terabaikannya hak-hak tersangka/terdakwa/terpidana dan korban kejahatan yang harus diperhatikan kemungkinan mendapatkan perlindungan hukum atas haknya sebagai korban kejahatan, tidak mendapat pengaturan yang memadai. KUHAP belum menunjukkan keberpihakan terhadap penderitaan korban yang seharusnya mendapatkan perlindungan dan jaminan haknya untuk memperoleh ganti rugi, rehabilitasi, baik secara lahir maupun batin. KUHAP juga tidak 
Atikah Rahmi, Urgensi Perlindungan bagi Korban Kekerasan Seksual dalam Sistem Peradilan Pidana Terpadu Berkeadilan Gender

mengatur secara khusus tentang perlindungan terhadap saksi yang merasa terancam keselamatan jiwa dan hartanya akibat memberikan keterangan terhadap kejahatan tertentu.

Pada prinsipnya, menurut Mardjono Reksodiputro, Sistem Peradilan Pidana (Criminal Justice System) adalah sistem yang dibuat untuk menanggulangi masalah-masalah kejahatan yang dapat mengganggu ketertiban dan mengancam rasa aman dalam suatu masyarakat. Konsep sistem peradilan pidana yang dikenal di Indonesia ialah suatu keadaan dimana terjalinnya hubungan yang bersifat fungsional dan instansional yaitu koordinasi di antara subsistem satu dengan lainnya menurut fungsi dan kewenangannya masing-masing sebagaimana fungsi dan kewenangan yang diatur dalam hukum acara pidana dalam rangka menegakkan hukum pidana yang berlaku (Marjono Reksodiputro, 1984). Sistem peradilan pidana yang terpadu diimplementasikan dalam 4 (empat) subsistem kekuasaan, yaitu: kekuasaan penyidikan, kekuasaan penuntutan, kekuasaan mengadili/menjatuhkan pidana dan kekuasaan eksekusi/pelaksanaan pidana (Barda Nawawi Arief, 2007).

Tujuan yang ingin dicapai dari pelaksanaan sistem peradilan pidana antara lain:

a) Mencegah masyarakat menjadi korban kejahatan

b) Menyelesaikan kasus kejahatan yang terjadi sehingga masyarakat puas bahwa keadilan telah ditegakkan dan yang bersalah dipidana

c) Mengusahakan agar mereka yang pernah melakukan kejahatan tidak lagi mengulanginya (Edi Setiadi. Kristian, 2017).

Semua tujuan di atas hanya dapat dicapai bila proses yang berlangsung dalam sistem tersebut berlangsung secara terpadu, sehingga dikenal istilah SPP Terpadu (Integrated Criminal Justice System). Sebuah SPP Terpadu memiliki beberapa karakteristik tertentu, yaitu: integration (coordination dan syncronization), clear aims, process (inputthrougput-output), dan effective control mechanism (Muladi).

Pada tanggal 23 November 2011 suatu kesepakatan bersama dihasilkan dari Komisi Nasional Anti Kekerasan Terhadap Perempuan, Mahkamah Agung RI, Kejaksaan RI, Kepolisian RI, Kementerian Pemberdayaan Perempuan dan Perlindungan Anak RI serta Perhimpunan Advokat Indonesia (Peradi). MOU tersebut berisikan 3 hal, yaitu; 1) Pendidikan dan Pelatihan khususnya dilakukan di setiap APH, 2). Sistem Peradilan Pidana Terpadu Penanganan Kasus Kekerasan Terhadap Perempuan (SPPT-PKKTP), 3). Monitoring dan evaluasi (Monev).

Pasal 1 angka (6) hasil MOU antara Komisi Nasional Anti Kekerasan Terhadap Perempuan, Mahkamah Agung RI, Kepolisian Negara RI, Kementerian Pemberdayaan Perempuan dan Perlindungan Anak RI dan Perhimpunan Advokat Indonesia disebutkan bahwa Sistem peradilan pidana terpadu penanganan kasus-kasus kekerasan terhadap perempuan ialah sistem terpadu yang menunjukkan proses keterkaitan antar instansi/pihak yang berwenang menangani kasus kekerasan terhadap perempuan dan akses pelayanan yang 
mudah dan terjangkau bagi perempuan dalam setiap proses peradilan kasus kekerasan terhadap perempuan.

Prinsip-prinsip yang terkandung dalam Sistem Peradilan Pidana Terpadu terdapat dalam UU No. 7 Tahun 1984 Tentang Ratifikasi Konvensi Penghapusan Segala Bentuk Kekerasan Terhadap Perempuan dan peraturan perundangan yang terkait dengan Hak Asasi Manusia (HAM), antara lain;

1. Perlindungan dan penegakan atas Hak Asasi Manusia

Konsep Sistem Peradilan Pidana Terpadu Penanganan Kasus Kekerasan Terhadap Perempuan (SPPT-PKKTP) ini harus dilandasi oleh semangat untuk pemenuhan hak asasi manusia, khususnya Hak Asasi Manusia (HAM) yang paling mendasar seperti hak hidup, hak atas kebebasan dan hak atas keamanan. Konsep ini dibuat untuk menghapuskan segala bentuk diskriminasi terhadap korban, dalam hal ini perempuan dan dalam rangka memenuhi hak-hak asasi manusia itu.

2. Kesetaraan dan Keadilan gender. Gender adalah suatu konsep yang mengacu pada sistem hubungan sosial yang membedakan peran perempuan dan laki-laki dalam masyarakat yang dibangun atau dikonstruksi secara sosial cultural. Selama ini dalam pelaksanaannya seringkali perempuan menjadi korban dari ketidakadilan gender ini. Oleh karenanya konsep ini harus didasari oleh semangat utama untuk memperjuangkan kesetaraan dan keadilan gender khususnya bagi perempuan korban kekerasan. Kesetaraan gender adalah suatu keadaan dimana perempuan dan lakilaki menikmati status yang setara dan berada dalam kondisi yang sama untuk mewujudkan secara penuh hakhak asasi dan potensinya dalam semua bidang kehidupan. Keadilan gender merupakan suatu kondisi yang adil bagi perempuan dan laki-laki melalui suatu proses cultural dan structural yang menghentikan hambatan-hambatan aktualisasi bagi pihak-pihak yang oleh karena jenis kelaminnya mengalami hambatan, baik secara kultural maupun secara struktural.

3. Perlindungan terhadap korban

Konsep ini dilandasi oleh semangat terhadap perlindungan dan penegakan hak-hak korban yakni hak untuk memperoleh kebenaran, keadilan dan reparasi.

4. Prinsip Non-diskriminasi

Ketidaksetaraan antara perempuan dan laki-laki adalah hasil dari konstruksi sosial, karena itu harus ada usaha untuk menghapuskannya agar tidak terjadi diskriminasi. CEDAW sendiri mendefinisikan diskriminasi sebagai setiap perbedaan, pengucilan, atau pembatasan yang dibuat atas dasar jenis kelamin.

Keempat prinsip tersebut menjadi muatan dalam Sistem Peradilan Pidana Terpadu Penanganan Kasus Kekerasan Terhadap Perempuan.Ruang lingkup SPPT-PKKTP yaitu perempuan yang mengalami kekerasan yang ditempatkan sebagai korban atau "pelaku" dalam proses peradilan. Kekerasan yang dimaksud meliputi tindakan berdasarkan perbedaan jenis kelamin yang berakibat atau mungkin berakibat pada kerugian 
Atikah Rahmi, Urgensi Perlindungan bagi Korban Kekerasan Seksual dalam Sistem Peradilan Pidana Terpadu Berkeadilan Gender

fisik, seksual, psikologis dan ekonomi, pemaksaan atau penghilangan kebebasan secara sewenang-wenang baik yang terjadi sifatnya umum maupun dalam kehidupan pribadi.

Sistem Peradilan Pidana yang Terpadu (SPPT) atau Integrated Criminal Justice System (ICJS) merupakan instrumen hukum yang sangat penting dalam kerangka penegakan hukum pidana materiil. Sistem Peradilan Pidana Terpadu Penanganan Kasus Kekerasan Terhadap Perempuan (SPPT-PKKTP) merupakan sistem terpadu yang menunjukkan proses keterkaitan antara instansi atau pihak yang berwenang manangani kasus kekerasan terhadap perempuan dan akses pelayanan yang mudah serta terjangkau bagi korban dalam setiap proses peradilan kasus kekerasan terhadap perempuan. Lingkup Sistem Peradilan Pidana Terpadu Penanganan Kasus Kekerasan Terhadap Perempuan(SPPT-PKKT) adalah untuk perempuan yang mengalami kekerasan (perempuan korban kekerasan) yang ditempatkan sebagai "korban" atau "pelaku" dalam proses peradilan. Kebutuhan dan kepentingan korban dengan mengacu pada nilai-nilai yang adil gender menjadi dasar dan upaya membangun Sistem Peradilan Pidana Terpadu dalam Penanganan Kasus Kekerasan Terhadap Perempuan (SPPTPKKTP). SPPT-PKKTP menekankanpada perspektif korban yang mensyaratkan korban menjadi pusat berjalannya sistem peradilan.

Sistem peradilan pidana terpadu sangat efektif untuk diberlakukan dalam penanganan kasus kekerasan seksual terhadap perempuan dan anak. Kerjasama yang sinergis antara Lembaga Swadaya
Masyarakat (LSM), Rumah Sakit, Pusat Pelayanan Terpadu, Rumah Aman (Shelter), Kejaksaan dan Pengadilan. Koordinasi antar lembaga tersebut dapat menciptakan sinergisitas penanganan kasus kekerasan seksual terhadap perempuan dan anak, sehingga korban mendapatkan perlindungan.

Melalui Sistem Peradilan Pidana Terpadu Penanganan Kasus Kekerasan Terhadap Perempuan dan Anak (SPPTPKKTPA) korban akan diposisikan sebagai subjek (pelaku utama), bukan sebagai objek (pelengkap) yang hanya diambil pengakuannya saja. Sebagai Subjek dia berhak didengar keterangannya, mendapatkan informasi atas upaya-upaya hukum yang berjalan, dipertimbangkan rasa keadilan yang ingin diperolehnya dan dipulihkan situasi dirinya atas perampasan hak-haknya dan kekerasan yang dialaminya. Memposisikan perempuan korban sebagai subjek pada Sistem Peradilan Pidana Terpadu Penanganan Kasus Kekerasan Terhadap Perempuan (SPPT-PKKTP) diharapkan sudah dilakukan sejak terjadinya kasus, pada pendampingan dan penanganan pertama terhadap korban (medis, sosial, dan psikologis), penanganan hukum yang meliputi pelaporan kasus kepolisian, penyelidikan, penyidikan, pemeriksaan di tingkat peradilan, putusan peradilan, dan eksekusi putusan peradilan.

Sistem peradilan pidana terpadu didasarkan pada keseimbangan antara tindak pidana (daad) dan pelaku (dader) tindak pidana tersebut. Muladi mendasarkan pandangannya pada tujuan atau fungsi ganda Hukum Pidana, yaitu: (a) Secara primer berfungsi sebagai sarana penanggulangan kejahatan yang rasional; 
dan (b) Secara sekunder, sebagai sarana pengaturan tentang kontrol sosial, baik yang dilaksanakan secara spontan atau dibuat oleh negara dengan alat perlengkapannya. Dalam fungsi sekunder inilah Hukum Pidana modern bertujuan untuk policing the police, yaitu melindungi warga masyarakat dari campur tangan penguasa yang mungkin menggunakan pidana sebagai sarana secara tidak benar.

Berdasarkan sistem peradilan pidana terpadu, lembaga atau instansi yang bekerja dalam penegakan hukum, meskipun tugasnya berbeda-beda dan secara internal mempunyai tujuan sendirisendiri, tetapi pada hakikatnya masingmasing subsistem dalam sistem peradilan pidana tersebut saling bekerjasama dan terikat pada satu tujuan yang sama. Hal ini bisa terjadi jika didukung adanya sinkronisasi dari segi substansi yang mencakup produk hukum di bidang sistem peradilan pidana yang memungkinkan segenap subsistem dapat bekerja secara koheren, koordinatif dan integratif.

Kebutuhan dan kepentingan korban dengan mengacu pada nilai yang adil jender menjadi dasar dan upaya membangun Sistem Peradilan Pidana Terpadu dalam Penanganan Kasus Kekerasan Terhadap Perempuan (SPPTPKKTP). Dengan demikian SPPT-PKKTP bertitik tekan pada perspektif korban yang mensyaratkan korban menjadi atau diletakkan pada pusat berjalannya sistem peradilan. Pihak-pihak yang terkait dalam Sistem Peradilan Pidana Terpadu Penanganan Kasus Kekerasan Terhadap Perempuan (SPPT-PKKTP) ini adalah :1) Pendamping korban sebagai relawan pendamping, ahli medis, psikolog, dan hukum (advokat dan paralegal), 2).
Penyedia layanan rumah sakit, 3) Pengada layanan rumah aman (Women Crisis Centre), 4) Instansi polisi atau awak Ruang Pelayanan Khusus (RPK), 5) Para jaksa dan Instansi Kejaksaan, 6) Lingkup peradilan: panitera, hakim, instansi kehakiman, 7)Instansi rumah tahanan dan 8) lembaga pemasyarakatan (lapas).

Prinsip utama yang terdapat di dalam Undang-Undang No. 7 tahun 1984 tentang Ratifikasi Konvensi Penghapusan Segala Bentuk Diskriminasi terhadap Perempuan, Undang-Undang No. 23 tahun 2004 tentang Penghapusan Kekerasan dalam Rumah Tangga, ataupun perundang-undangan lainnya yang berkaitan dengan Hak Asasi Manusia (HAM), diadopsi dalam Sistem Peradilan Pidana Terpadu Penanganan Kasus Kekerasan Terhadap Perempuan (SPPTPKKTP) ini. Melalui Sistem Peradilan Pidana Terpadu dalam Penanganan Kasus Kekerasan Terhadap Perempuan (SPPTPKKTP) korban akan diposisikan sebagai subjek (pelaku utama), bukan sebagai objek (pelengkap) yang hanya diambil pengakuannya saja. Sebagai Subjek korban berhak didengar keterangannya, mendapatkan informasi atas upaya-upaya hukum yang berjalan, dipertimbangkan rasa keadilan yang ingin diperolehnya dan dipulihkan situasi dirinya atas perampasan haknya dan kekerasan yang dialaminya.

Memposisikan perempuan korban sebagai subjek pada Sistem Peradilan Pidana Terpadu Penanganan Kasus Kekerasan Terhadap Perempuan (SPPTPKKTP) diharapkan sudah dilakukan sejak terjadinya kasus, pada pendampingan dan penanganan pertama terhadap korban (medis, sosial, dan psikologis), 
Atikah Rahmi, Urgensi Perlindungan bagi Korban Kekerasan Seksual dalam Sistem Peradilan Pidana Terpadu Berkeadilan Gender

penanganan hukum yang meliputi pelaporan kasus kepolisian, penyelidikan, penyidikan, pemeriksaan di tingkat peradilan, putusan peradilan, dan eksekusi putusan peradilan.Perlu adanya konsep sistem penegakan hukum yang berkeadilan gender dengan menggali pengalaman para pihak yang terlibat dalam penanganan kasus kekerasan terhadap anak dan perempuan.

Sudah saatnya bagi aparat penegak hukum baik kepolisian, jaksa, maupun hakimtermasuk advokat, menyatukan persepsi untuk menjadikan kasus kekerasan seksual ini sebagai prioritas, karena kasus tersebut bukan lagi kejahatan kesusilaan akan tetapi sudah termasuk kejahatan kemanusiaan dan dikategorikan sebagai kejahatan yang luar biasa (extra ordinary crime). Pemerintah sendiri sudah berusaha untuk membuat peraturan yang memberlakukan hukuman berat kepada pelaku kekerasan seksual. Pihak kepolisian harus lebih tanggap menangani kasus kekerasan seksual sama seperti kejahatan lainnya seperti narkoba, pencurian dan sebagainya, ketika sudah cukup bukti, maka cepat dinaikkan kasusnya, tidak ditunda-tunda. Terkait dengan anggaran, mestinya pemerintah daerah sudah harus memberikan anggaran yang cukup tinggi dalam penanganan kasus kekerasan seksual anak ini. Hal ini dikarenakan polisi sering mengeluh tentang kendala anggaran yang tidak cukup untuk melakukan penangkapan, sehingga terkadang dibebankan kepada korban.

Begitu juga dengan personil kepolisian, Jaksa dan Hakim yang memiliki perspektif perempuan dan anak hendaknya diperbanyak dengan memberikan pelatihan kepada mereka. Aparat penegak hukum yang menangani kasus kekerasan seksual terhadap anak dan perempuan, hendaknya adalah aparat penegak hukum yang berperspektif anak dan perempuan agar dapat menjalankan tugasnya dengan baik sesuai dengan aturan hukum yang berlaku. Sehingga, penegakan hukum dapat terwujud, dengan demikian, korbanpun akan merasa dilindungi dan tepenuhinya rasa keadilan di masyarakat.

Kampanye atau berbagai bentuk advokasi anti kekerasan terhadap anak akan banyak membantu counsciousness raising dan pemberdayaan korban sehingga korban memiliki keberanian untuk membahas masalah kekerasan yang dialaminya, meninggalkan rasa malu dan tabu. Kejahatan seksual diperkirakan dapat menurun jika produk dan proses hukum sungguh-sungguh dapat menjerat pelaku dengan hukuman setimpal, dan masyarakat menunjukkan keberpihakannya pada korban dengan menyediakan berbagai bentuk dukungan sosial yang nyata.Pemerintah juga harusnya membuat kebijakan khusus tentang kasus kekerasan seksual ini agar menjadi kasus yang sangat mendesak dengan harapan negara akan menjamin pemenuhan hak korban dan keluarga korban untuk mendapatkan keadilan, kebenaran, dan pemulihan.

\section{SIMPULAN}

Sistem peradilan yang dibangun dalam penanganan kasus kekerasan terhadap perempuan dan anakadalah sistem peradilan yang mudah, terjangkau dan dapat dipertanggungjawabkan.Perlu dilakukan pendekatan yang besifat 
parsipatoris dengan melibatkan seluruh pihak yang berkepentingan untuk mengenalkan konsep sistem penegakan hukum yang berperspektif keadilan. Selain itu juga perlu mengenalkan konsep sistem penegakan hukum yang berkeadilan gender dengan menggali pengalaman para pihak yang terlibat dalam penanganan kasus kekerasan terhadap anak dan perempuan.

Pengenalan konsep Sistem

Peradilan Pidana Terpadu Penanganan Kasus Kekerasan Terhadap Perempuan dan Anak secara perlahan-lahan dilakukan dan didiskusikan bersama hingga mencapai satu persepsi dan pemahaman yang sama. Aparat penegak hukum yang menangani kasus kekerasan seksual terhadap anak dan perempuan, hendaknya adalah aparat penegak hukum yang memiliki perspektif anak dan perempuan agar dapat menjalankan tugasnya dengan baik sesuai dengan aturan hukum yang berlaku sehingga dapat menjerat pelaku setimpal dengan kejahatan yang dilakukannya. Sehingga, penegakan hukum dapat terwujud, dengan demikian, korbanpun akan merasa mendapatkan perlindungan dan tepenuhinya rasa keadilan di masyarakat.

\section{DAFTAR PUSTAKA}

\section{A. Buku-buku}

Abdul Wahid. Muhammad Irfan.2001.Perlindungan Terhadap Korban Kekerasan Seksual Advokasi atas Hak Asasi Perempuan. Refika Aditama: Bandung

Ahmad Sofian (Ed).2010. Memperkuat Hukum Penanganan Eksploitasi Seksual Anak. Ecpat Internasional

2012. Perlindungan Anak Di Indonesia Dilema dan Solusinya. PT. Sofmedia: Medan
Andika Wijaya, Wida Peace Ananta. 2016. Darurat Kejahatan Seksual. Sinar Grafika: Jakarta

Romli Atmasasmita. 1996. Sistem Peradilan Pidana (Perspektif Eksistensialisme dan Abolisionisme). Bandung.

Achie Sudiarti Luhulima (Penyunting). 2000. Pemahaman Bentuk-bentuk Tindak Kekerasan Terhadap Perempuan dan Alternatif Pemecahannya. PT. Alumni: Jakarta

Abu Huraerah.2006.Kekerasan Terhadap Anak. Nusantara: Bandung

Barda Nawawi Arif. 2001. Masalah Penegakan Hukum dan Kebijakan Penanggulangan Kejahatan,Bandung: PT Citra Aditya Bakti

Bambang Waluyo. 2011. Viktimologi Perlindungan Korban dan Saksi. Sinar Grafika: Jakarta

Dikdik M. Arief Mansur. Elisatris Gultom. 2008. Urgensi Perlindungan Korban Kejahatan Antara Norma dan Realita. PT. Raja Grafindo: Jakarta

Edi Setiadi. Kristian. 2017. Sistem Peradilan Pidana Terpadu Dan Sistem Penegakan Hukum Di Indonesia. Prenada Media: Jakarta.

Irma Setyowati Soemitro. 2012. Aspek Hukum Perlindungan Anak. Jakarta: PT. Rajawali Grasindo Persada.

Leden Marpaung. 1996. Kejahatan Terhadap Kesusilaan dan Masalah Prevensinya. Jakarta. Sinar Grafika.

Moeljatno. 1993. Asas-Asas Hukum Pidana. Jakarta: PT Rineka Cipta.

Mulyana W. Kusuma. 1988. Kejahatan Dan Penyimpangan. Jakarta: Yayasan LBH.

Marjono Reksodiputro, 1984. HAM dan Sistem Peradilan Pidana. Jakarta: Pusat Pelayanan Keadilan

Maidin Gultom. 2010. Perlindungan Hukum Terhadap Anak dalam Sistem Peradilan Pidana Anak di Indonesia. Bandung: Refika Aditama.

Muladi. 1998. Kapita Selekta Sistem Peradilan Pidana. Semarang: Penerbit UNDIP.

Mansur Fakih. 1996. Analisis Gender \& Transformasi Sosial. Pustaka Pelajar: Yogyakarta

Nasriana. 2012. Perlindungan Hukum Pidana Bagi Anak Di Indonesia. Jakarta: Raja Wali Pers. 
Atikah Rahmi, Urgensi Perlindungan bagi Korban Kekerasan Seksual dalam Sistem Peradilan

\section{Pidana Terpadu Berkeadilan Gender}

Niken Savitri. 2008. HAM Perempuan Kritik Teori Hukum Feminis Terhadap KUHP. Refika Aditama: Bandung

R. Susilo. 1995.Kitab Undang-Undang Hukum Pidana(KUHP),Bogor: Politelia.

Sulistiyono, Adi. 2006. Krisis Lembaga Peradilan di Indonesia. Surakarta: UNS Pres.

Sunaryati Hartono. 1991. Politik Hukum Menuju Satu Sistem Hukum Nasional. Bandung: Alumni.

Sidik Sunaryo. 2005. Kapita Selekta Sistem Peradilan Pidana. UMM Press: Malang

Siswanto Sunarso. 2015. Viktimologi Dalam Sistem Peradilan Pidana. Sinar Grafika: Jakarta

Wirjono Prodjodikoro. 2010. Tindak-Tindak Pidana Tertentu Di Indonesia. Bandung: PT Refika Aditama.

Zaitunah Subhan. 2015. Al Qur'an \&Perempuan Menuju Kesetaraan Gender Dalam Penafsiran. Prenada Media Grup: Jakarta

\section{B. Jurnal dan Artikel}

Ivo Noviana, Kekerasan Seksual Terhadap Anak: Dampak dan Penanganannya melaluihttps://media.neliti.com/media/publi cations/52819-ID-kekerasan-seksualterhadap-anak-dampak-d.pdf2015, diakses tanggal 05 Juli 2017

Mariana Amiruddin, "Kekerasan Seksual: Bukan Kejahatan Kesusilaan Melainkan Kriminal" Jurnal Perempuan, edisi 71.

Supriyanta, "KUHAP dan Sistem Peradilan Pidana Terpadu", Wacana Hukum, Vol VII, April 2009

Witriyatul Jauhariyah. "Akar Kekerasan Seksual Terhadap Perempuan" Jurnal Perempuan, melalui http://www.jurnalperempuan.org/blogmuda1/-akar-kekerasan-seksual-terhadapperempuan, diakses tanggal 06 Juni 2017 